\title{
Effects of Supplementation and Stage of Lactation on Performance of Grazing Dairy Ewes ${ }^{1}$
}

\author{
C. M. Mikolayunas, ${ }^{*} \dagger^{2}$ D. L. Thomas, ${ }^{*}$ K. A. Albrecht, $\dagger$ D. K. Combs, $\ddagger$ Y. M. Berger,§ and S. R. Eckerman* \\ *Department of Animal Sciences, \\ †Department of Agronomy, and \\ ‡Department of Dairy Science, University of Wisconsin-Madison, Madison 53706 \\ $\S$ Spooner Agricultural Research Station, University of Wisconsin-Madison, Spooner 54801
}

\begin{abstract}
The majority of dairy sheep in the world are fed pasture and supplemental grain during lactation; however, no trials have reported the effects of supplementation of dairy ewes grazing improved pastures in North America. In trial 1, 56 three-year-old grazing dairy ewes in early [ $21 \pm 10 \mathrm{~d}$ in milk (DIM)] or late $(136 \pm 9 \mathrm{DIM})$ lactation were fed 0 or $0.82 \mathrm{~kg}$ of dry matter/d per ewe of supplement ( $16.5 \%$ crude protein mixture of corn and a soybean meal-based high-protein pellet) in a $2 \times 2$ factorial arrangement of treatments. There were no significant interactions between stage of lactation and supplementation treatments. Average test-day milk production was higher in early-lactation ewes than in latelactation ewes (1.74 vs. $1.21 \mathrm{~kg} / \mathrm{d}$, respectively). Although test-day milk protein percentage was higher in late-lactation ewes than in early-lactation ewes (5.02 vs. $4.86 \%$, respectively), there was no difference in milk fat percentage between stages of lactation. Supplemented ewes had higher milk production (1.59 vs. 1.36 $\mathrm{kg} / \mathrm{d}$, respectively), lower milk fat percentage (5.75 vs. $6.00 \%$, respectively), and lower milk protein percentage (4.84 vs. $5.04 \%$, respectively) than unsupplemented ewes. Milk urea $\mathrm{N}$ levels were similar between the 2 stages of lactation and between the 2 supplementation treatments and were above recommended levels for dairy sheep, indicating an excess intake or inefficient utilization of protein for both supplementation treatments. In trial 2, 96 two-, three-, and four-year-old grazing dairy ewes in midlactation $(112 \pm 21 \mathrm{DIM})$ were randomly assigned to 4 treatments of $0,0.41,0.82$, or $1.24 \mathrm{~kg}$ of dry matter/d per ewe of whole corn. Average test-day milk production increased linearly and milk
\end{abstract}

Received June 20, 2007.

Accepted December 29, 2007.

${ }^{1}$ This research was supported by USDA/North Central RegionSustainable Agriculture Research and Education (project no. GNC05051) and University of Wisconsin-Madison Agricultural Experiment Station/USDA/Hatch (project no. 4795).

${ }^{2}$ Corresponding author: mikolayunas@wisc.edu fat percentage decreased quadratically with increasing amounts of corn supplementation. Milk protein yield increased linearly, and milk urea $\mathrm{N}$ levels decreased quadratically with increasing amounts of corn supplementation, suggesting an improvement in the utilization of pasture protein with increasing dietary energy intake.

Key words: dairy sheep, grazing, supplementation

\section{INTRODUCTION}

The dairy sheep industry in North America began approximately $25 \mathrm{yr}$ ago, and in 2003, approximately 75 farms in North America produced more than 1.5 million kg of sheep milk (Thomas, 2004). Most dairy sheep flocks are located in regions well suited to pasture production, such as southeastern Canada, New England, and the Upper Midwest. Although supplementation has been shown to have a positive effect on the milk production of grazing dairy cows in the Upper Midwest of the United States (Reis and Combs, 2000) and on dairy ewes grazing the native Mediterranean pastures of southern Europe (D'Urso et al., 1993), little information is available regarding the supplementation of dairy sheep on high-quality improved pastures.

Temperate regions support mixed grass-legume pastures, which can average more than $20 \%$ CP. Pasture $\mathrm{CP}$ is highly degradable in the rumen and can lead to the transport of large amounts of $\mathrm{NH}_{3}-\mathrm{N}$ across the rumen wall. The $\mathrm{NH}_{3}$ is converted to urea in the liver, and excess amounts are excreted in the milk or urine. Although improved pastures are high in levels of RDP, they are low in NFC, which are needed to support microbial growth and the production of VFA and milk. Supplemental grain can provide the NFC needed to utilize pasture RDP in dairy ewes grazing improved pastures.

Two grazing trials were conducted to 1) determine the effect of supplementation of corn and a soybean meal-based pellet on the performance of dairy ewes at different stages of lactation and 2) determine the effect of different levels of corn supplementation on the perfor- 
Table 1. Composition of supplement fed to grazing dairy ewes in trial 1

\begin{tabular}{lc}
\hline Item & Amount, \% of DM \\
\hline Ingredient & \\
Whole shelled corn & 75.0 \\
Soybean meal & 14.9 \\
Wheat middlings & 4.6 \\
Canola meal & 3.8 \\
Corn distillers grain with solubles & 1.3 \\
Molasses & 0.4 \\
Composition & \\
$\mathrm{CP}^{1}$ & 16.3 \\
$\mathrm{NDF}^{1}$ & 13.6 \\
$\mathrm{NFC}^{2}$ & 62.4 \\
$\mathrm{Ash}^{3}$ & 2.8 \\
$\mathrm{Fat}^{3}$ & 3.9 \\
\hline
\end{tabular}

${ }^{1}$ Based on chemical analysis of whole corn and pellet.

${ }^{2} \mathrm{NFC}=100-(\mathrm{NDF}+\mathrm{CP}+\mathrm{ash}+\mathrm{fat}+1)$.

${ }^{3}$ Based on the Cornell Net Carbohydrate and Protein System (Cannas et al., 2004).

mance of dairy ewes. In addition, both studies investigated the effects of supplementation treatments on protein utilization, as indicated by MUN levels.

\section{MATERIALS AND METHODS}

\section{Ewes}

The grazing trials were conducted in 2005 (trial 1) and 2006 (trial 2) at the University of Wisconsin-Madison, Spooner Agricultural Research Station, and all procedures were approved by the Animal Care and Use Committee of the College of Agricultural and Life Sciences. In trial 1, 56 three-year-old ewes were arranged in a $2 \times 2$ factorial treatment design. Ten ewes in early lactation $(21 \pm 10 \mathrm{DIM} ; 5$ ewes per supplementation treatment) and 46 ewes in late lactation (136 \pm 9 DIM; 23 ewes per supplementation treatment) at the start of the trial were randomly assigned to 2 supplementation treatments, receiving 0 or $0.82 \mathrm{~kg}$ of $\mathrm{DM} / \mathrm{d}$ per ewe of supplement during the grazing period. Supplement treatments began on May 25, 2005, and lasted $82 \mathrm{~d}$, until August 15, 2005. The supplement used was the one historically fed at the Spooner Agricultural Research Station and was a mixture of whole shelled corn and a soybean meal-based pellet (CSBM). Ingredient and nutrient composition of the supplement is presented in Table 1.

All lambs were weaned from their ewes at 36 to 48 $\mathrm{h}$ postpartum, and ewes were machine milked twice daily in a double-12 parlor at 0530 and $1700 \mathrm{~h}$ beginning at weaning. All ewes were provided $0.41 \mathrm{~kg}$ of supplement DM in an individual feeder in the parlor at each milking and an average of $1.9 \mathrm{~kg}$ of $\mathrm{DM} / \mathrm{d}$ of alfalfa silage in a group feeder in drylot until grazing began and supplementation treatments were applied. All ewes had access to the same pastures for approximately 20 $\mathrm{h} / \mathrm{d}$. Ewes were provided water in the pasture and a free-choice mineral-salt mixture in the parlor holding area; no shade was provided in the pastures. Supplementation treatment groups had a similar mean milk production on either previous test days in the current lactation (late-lactation ewes) or the previous year's milk yield (early-lactation ewes).

In addition to the 56 three-year-old ewes in trial 1 , 20 two-year-old ewes and 19 four-year-old ewes in late lactation were divided between the unsupplemented and supplemented treatments and managed with the 56 three-year-old ewes during the entire trial. The final analyses of milk production, milk composition, BW change, and BCS change did not include data from these two- and four-year-old ewes because ewe age has a large effect on milk yield, and inclusion of these ewes would have confounded the effects of ewe age and stage of lactation. Composite milk samples from 8 to 10 ewes from each treatment were taken during the trial period and submitted to a commercial laboratory for analysis of MUN levels (24 total composite samples). The twoyear-old $(\mathrm{n}=5)$ and four-year-old $(\mathrm{n}=10)$ ewes were among the 18 late-lactation ewes sampled for MUN analysis.

In trial 2, 96 two-, three-, and four-year-old ewes, averaging $112 \pm 21 \mathrm{DIM}$ at the start of the trial, were blocked by age ( 2 yr old or $>2$ yr old) and randomly assigned to 4 supplementation treatments of $0,0.41$, 0.82 , or $1.24 \mathrm{~kg}$ of $\mathrm{DM} / \mathrm{d}$ per ewe of whole corn $(7.8 \%$ CP, $20.1 \%$ NDF). Treatment groups had similar mean milk yields for both the previous milk test and the previous years' total lactation. Lamb management and ewe milking schedule were the same as in trial 1. From lambing, all ewes were individually fed $0.82 \mathrm{~kg}$ of DM/ $\mathrm{d}$ of whole corn in the parlor and group-fed an average of $1.9 \mathrm{~kg}$ of DM/d of alfalfa silage in a drylot until grazing began on May 25, 2006, when supplementation treatments were started. Supplementation treatments continued for 88 d, until August 21, 2006.

\section{Pastures}

Both trials used the same 8.1 ha of pasture, which ranged in composition from a mixture of approximately $60 \%$ kura clover (Trifolium ambiguum Bieb.) and $40 \%$ orchardgrass (Dactylis glomerata L.) and perennial ryegrass (Lolium perenne L.) to 5\% kura clover and 95\% orchardgrass, Kentucky bluegrass (Poa pratensis L.), and quackgrass (Agropyron repens L.). The pastures were divided into approximately 0.6-ha paddocks by using a combination of permanent and portable electric fencing. Ewes were moved to a new paddock at 2- to 4- 
d intervals, which allowed for at least $2.84 \mathrm{~kg}$ of pasture $\mathrm{DM} /$ ewe per d in 2005 and $3.79 \mathrm{~kg}$ of pasture DM/ewe per $d$ in 2006. The interval between grazing events in each paddock was approximately 3 wk. After grazing, each paddock was clipped to a height of approximately $7.5 \mathrm{~cm}$ to remove ungrazed forage and allow for consistent regrowth.

\section{Sample Collection, Analysis, and Calculations}

Milk yield recording and milk sampling for fat and protein analyses were the same for both trials. Daily milk production of individual ewes was measured weekly with a graduated Waikato Goat Meter (Waikato Milking Systems NZ Ltd., Hamilton, New Zealand) by combining the amount of milk obtained at an evening and subsequent morning milking. Every 2 wk, milk samples from the morning milking were analyzed for percentages of fat and protein (AgSource Milk Labs, Stratford, WI). In trial 1, a compiled milk sample from 8 to 10 ewes in each of the 4 treatment combinations was analyzed every 2 wk for MUN by using a Foss FT6000 (Foss Electric, Hillerød Denmark; AgSource Milk Labs, Stratford, WI). In trial 2, individual milk samples of 8 to 10 ewes per treatment were analyzed for MUN every 2 wk by using an enzymatic procedure adapted from Chaney and Marbach (1962). In the modified procedure, samples were centrifuged $(10,000 \times g)$ for $5 \mathrm{~min}$ and stored at $2^{\circ} \mathrm{C}$ for $30 \mathrm{~min}$, and fat was removed with a metal scoupula. Enzymatic analysis of MUN was performed on the supernatant. In both trials, ewes were weighed every 2 wk and body condition was scored once per month $(1=$ very thin, 5 = very fat; Boundy, 1982). Body weight change and BCS change were calculated as initial BW or BCS minus final BW or BCS, respectively.

Daily milk production, milk fat percentage, and milk protein percentage were used to calculate $6.5 \% \mathrm{FCM}$ and $6.5 \%$ fat- and $5.8 \%$ protein-corrected milk (FPCM) based on the following equations developed by Pulina et al. (1989):

$$
\begin{gathered}
\mathrm{FCM}=\mathrm{M}[0.37+(0.097 \times \mathrm{F})] \text {, and } \\
\mathrm{FPCM}=\mathrm{M}[0.25+(0.085 \times \mathrm{F})+(0.035 \times \mathrm{P})],
\end{gathered}
$$

where $\mathrm{M}$ is milk yield $(\mathrm{kg})$ and $\mathrm{F}$ and $\mathrm{P}$ are fat and protein concentration (\%), respectively.

In both trials, pasture samples were collected from paddocks approximately twice per week. Four quadrats $\left(0.37 \mathrm{~m}^{2}\right)$ were tossed randomly throughout the paddock before a grazing event, and forage was harvested to 2.5 $\mathrm{cm}$ stubble height. Forage samples were weighed and oven-dried $\left(37^{\circ} \mathrm{C}\right.$ forced-air oven) until they reached a constant weight. In trial 1 , a composite of the 4 pregraz- ing forage samples from each pasture was ground to pass through a 1-mm screen in a Udy cyclone mill (Udy Corp., Fort Collins, CO) before laboratory analysis. Forage, corn, and pellet samples were analyzed for DM, and NDF was determined by using the method of Robertson and Van Soest (1981) as modified by Hintz et al. (1996) and Mertens (2002). In trial 2, a composite of the 4 pregrazing forage samples from each pasture was ground to pass through a 2-mm screen in a Udy cyclone mill before laboratory analysis. Forage and corn samples were analyzed for DM, and NDF was determined by using a neutral detergent solution containing sodium sulfite and $\alpha$-amylase in an Ankom200 Fiber Analyzer (Goering and Van Soest, 1970). In both trials, CP was calculated as $\mathrm{N}$ concentration $\times 6.25$. Nitrogen concentration was determined by rapid combustion $\left(850^{\circ} \mathrm{C}\right)$, conversion of all $\mathrm{N}$-combustion products to $\mathrm{N}_{2}$, and measurement by a thermoconductivity cell (Leco Model FP528, Leco Corp., St. Joseph, MI).

Pregrazing herbage mass ( $\mathrm{kg}$ of $\mathrm{DM} / \mathrm{ha}$ ) and pasture allowance (kg of DM/ewe per d) were measured by using a rising plate meter placed in 25 random locations throughout the paddock. The plate meter $(1,254 \mathrm{~g}$ and $0.16 \mathrm{~m}^{2}$ ) was calibrated to each pasture by correlating the DM and rising plate reading of 20 clipped samples as described by Bransby et al. (1977). Pasture calibration was repeated twice in both the early and midgrazing season to account for changes in pasture composition and maturity over time. Postgrazing pasture residue was estimated once per week with the rising plate meter to verify sufficient pasture allowance.

\section{Statistical Analyses}

In trial 1, milk production and milk composition were analyzed by using the MIXED procedure of SAS (version 8.2, SAS Institute Inc., Cary NC) for a factorial design with repeated measures. The model for these repeated measures included the fixed effects of stage of lactation, supplementation treatment, test date, and their 2- and 3-way interactions; the random effects of ewe and residual; and an autoregressive covariate for repeated measures on each ewe. Body weight change, BCS change, and MUN were analyzed by using the MIXED procedure of SAS (version 8.2). The model included the fixed effects of stage of lactation, supplementation treatment, their interaction, and the random residual. All values presented are least squares means and standard errors of the mean, and significant differences between least squares means were declared at $P$ $<0.05$ unless otherwise noted. Pasture CP was related to MUN by using the CORR procedure of SAS.

In trial 2, milk, fat, and protein production; milk composition; and MUN were analyzed by using the 
Table 2. Mean pasture quality of weekly samples of mixed grasslegume pastures grazed during trial 1 (2005) or trial 2 (2006)

\begin{tabular}{lccccc}
\hline \multirow{2}{*}{$\begin{array}{l}\text { Component, } \\
\text { \% of DM }\end{array}$} & \multicolumn{2}{c}{ Trial 1} & & \multicolumn{2}{c}{ Trial 2} \\
\cline { 2 - 3 } \cline { 5 - 6 } & $\mathrm{n}$ & Mean \pm SEM & & $\mathrm{n}$ & Mean \pm SEM \\
\hline NDF & 30 & $36.0 \pm 9.1$ & & 22 & $47.7 \pm 12.0$ \\
CP & 30 & $24.2 \pm 4.1$ & & 22 & $20.6 \pm 9.1$ \\
\hline
\end{tabular}

MIXED procedure of SAS (version 9.1, SAS Institute Inc.) with repeated measures for a completely randomized design. The model included the fixed effects of supplementation treatment, test date, their interaction, and ewe age ( $2 \mathrm{yr}$ old or $>2 \mathrm{yr}$ old); the random effects of ewe and residual; and an autoregressive covariate for repeated measures on each ewe. Body weight change and BCS change were analyzed by using the MIXED procedure of SAS, and the model included the fixed effect of supplementation treatment and the random residual. All values presented are least squares means and standard errors of the mean. Differences between least squares means were calculated by using a TukeyKramer adjustment for multiple comparisons of means. Significant differences were declared at $P<0.05$ unless otherwise noted. Orthogonal contrasts were calculated in PROC MIXED to evaluate linear and quadratic responses to the level of supplementation.

\section{RESULTS AND DISCUSSION}

\section{Pastures}

In both trial years, the Spooner Agricultural Research Station experienced summer drought conditions, but high pasture quality (Table 2 ) and availability were obtained by overhead irrigation and pasture management. In trial 1, herbage availability before ewes entered each paddock ranged from 854 to $2,561 \mathrm{~kg}$ of $\mathrm{DM} / \mathrm{ha}$, with an average of $1,504 \mathrm{~kg}$ of DM/ha. Pregrazing allowance was at least $2.84 \mathrm{~kg}$ of DM/ewe per d. Postgrazing herbage availability, measured once per week, was always greater than $4.24 \mathrm{~kg}$ of DM/ewe. Herbage mass per hectare before grazing was highest at the beginning of the season and decreased toward the end of the summer. In trial 2, herbage availability ranged from 1,147 to $4,421 \mathrm{~kg}$ of $\mathrm{DM} / \mathrm{ha}$ before ewes entered the paddock. Pregrazing allowance was at least $6.25 \mathrm{~kg}$ of DM/ewe per d and postgrazing herbage availability was at least $3.42 \mathrm{~kg}$ of DM/ewe. In both trials, ewes had sufficient pasture DM available.

\section{Trial 1}

Milk Production and Composition. The stage of lactation $\times$ supplementation treatment interaction was
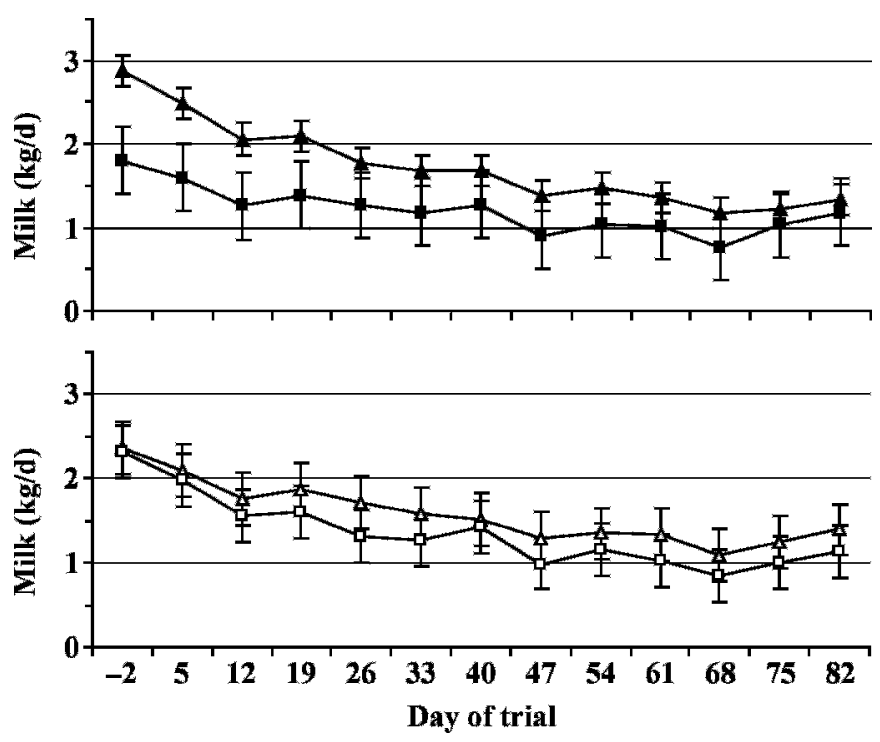

Figure 1. Mean test-day milk yield for the main effects of stage of lactation (upper graph) and supplementation (lower graph) treatments: early lactation $(\boldsymbol{\Lambda}, 21 \pm 10 \mathrm{DIM})$ and late lactation $(\mathbf{\square}, 139 \pm$ 9 DIM) at the start of the trial, and supplementation level of 0 ( $\square$ ) and $0.82(\triangle) \mathrm{kg}$ of DM/d per ewe. Error bars indicate SEM.

not a significant source of variation for any trait. Therefore, the least squares means within test days for milk yield, milk fat, and milk protein by the main effects of stage of lactation and supplementation treatment are plotted in Figures 1, 2, and 3, respectively.
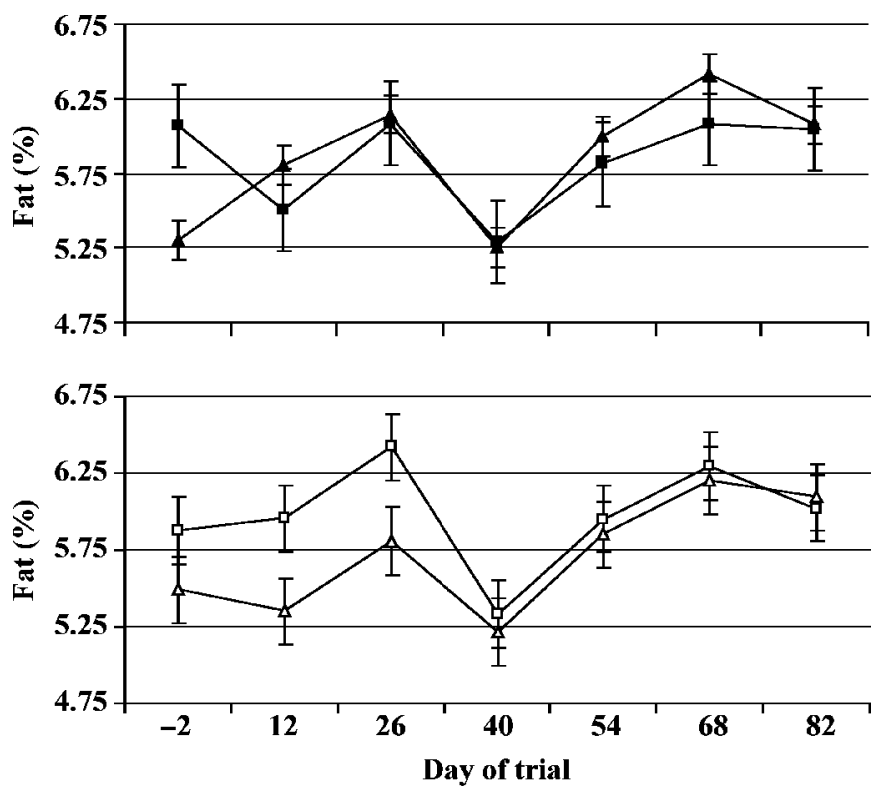

Figure 2. Mean test-day milk fat percentage for the main effects of stage of lactation (upper graph) and supplementation (lower graph) treatments: early lactation $(\boldsymbol{\Lambda}, 21 \pm 10$ DIM) and late lactation ( $139 \pm 9$ DIM) at the start of the trial, and supplementation level of $0(\square)$ and $0.82(\triangle) \mathrm{kg} \mathrm{DM} / \mathrm{d}$ per ewe. Error bars indicate SEM. 

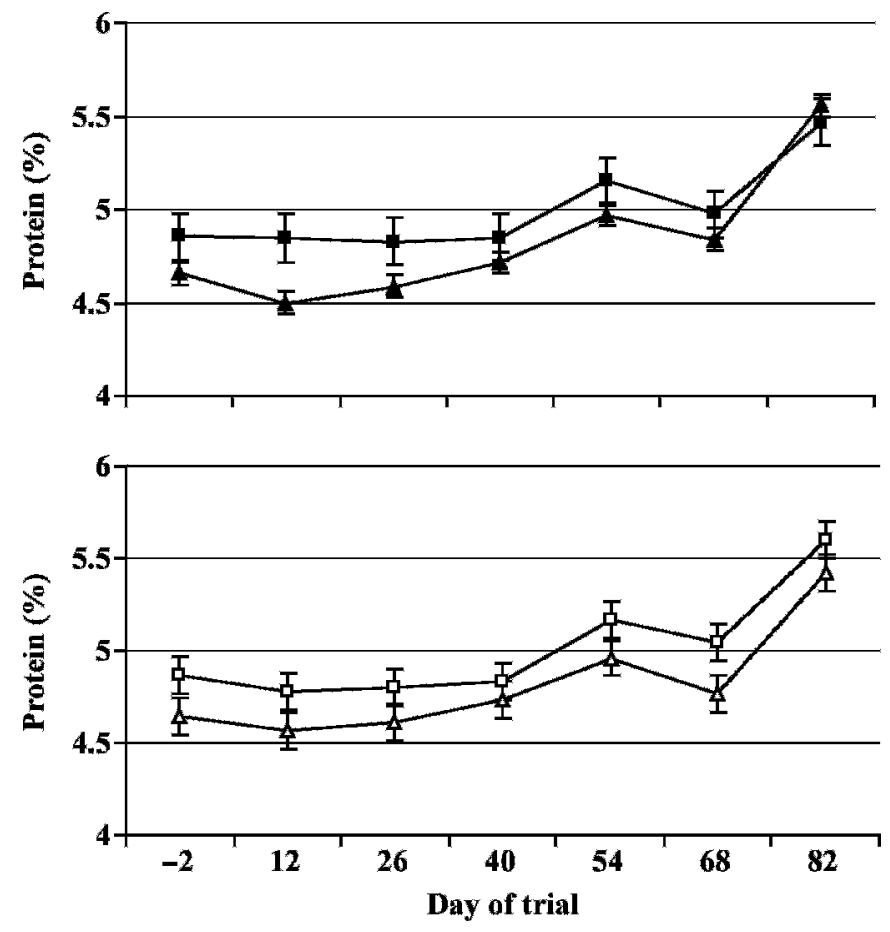

Figure 3. Mean test-day milk protein percentage for the main effects of stage of lactation (upper graph) and supplementation (lower graph) treatments: early lactation $(\boldsymbol{\Lambda}, 21 \pm 10 \mathrm{DIM})$ and late lactation (, $139 \pm 9$ DIM) at the start of the trial, and supplementation level of $0(\square)$ and $0.82(\triangle) \mathrm{kg}$ of DM/d per ewe. Error bars indicate SEM.

Least squares means of stage of lactation and supplementation treatments averaged across test days are presented in Table 3. Early-lactation ewes produced more $(P=0.001)$ daily milk $(+0.53 \mathrm{~kg}), \mathrm{FCM}(+0.36 \mathrm{~kg})$, and FPCM $(+0.34 \mathrm{~kg})$ than late-lactation ewes. Because milk production generally peaks in the fourth week of lactation and then slowly declines (Carta et al., 1995), the early-lactation ewes were expected to have greater daily milk yields than late-lactation ewes during the trial. Supplemented ewes produced more $(P<0.01)$ daily milk (+0.23 kg), FCM (+0.16 kg), and FPCM (+0.14 $\mathrm{kg}$ ) than unsupplemented ewes (Table 3 ). This supports the work of D'Urso et al. (1993), in which supplementation of grazing ewes with a mixture of corn, soybeans, and barley increased milk production.

Late-lactation ewes had a higher $(P<0.05)$ milk fat percentage than early-lactation ewes before the start of the trial, but stage of lactation was not a significant source of variation during the trial (Figure 2 and Table $3)$. Unsupplemented ewes had a higher $(P=0.054)$ average test-day milk fat percentage than supplemented ewes (Table 3). This may have resulted from the negative association between energy balance and milk fat concentration in dairy ewes (Pulina et al., 2007). Ewes in negative energy balance mobilize more body fat to contribute to milk fat synthesis, especially in early lactation. In addition, there is a positive relationship between dietary fiber and milk fat in dairy ewes (Nudda et al., 2002). Supplemented ewes may have consumed lower NDF diets because of both low NDF in the supplement (Table 2) and lower pasture intake resulting from the substitution effect of supplementation. In grazing Italian dairy ewes, the degree to which supplement intake substitutes for intake of grazed forage is related to energy demands for milk production and pasture quality, but substitution is observed even in high-quality pastures (Avondo, 2005). On test days 12 and 26, when supplemented ewes had a numerically lower fat percentage than unsupplemented ewes (Figure 2), pas-

Table 3. Performance of grazing dairy ewes by stage of lactation and supplementation treatments in trial 1

\begin{tabular}{|c|c|c|c|c|c|c|c|c|c|c|}
\hline \multirow[b]{2}{*}{ Item } & \multicolumn{5}{|c|}{ Stage of lactation ${ }^{1}$} & \multicolumn{5}{|c|}{ Supplement level } \\
\hline & $\mathrm{n}^{3}$ & Mean \pm SEM & $\mathrm{n}$ & Mean \pm SEM & $P$-value & $\mathrm{n}$ & Mean \pm SEM & $\mathrm{n}$ & Mean \pm SEM & $P$-value \\
\hline Milk, kg & 598 & $1.74 \pm 0.02$ & 130 & $1.21 \pm 0.05$ & 0.001 & 364 & $1.36 \pm 0.04$ & 364 & $1.59 \pm 0.04$ & 0.001 \\
\hline Fat, $\%$ & 276 & $5.95 \pm 0.05$ & 60 & $5.80 \pm 0.11$ & 0.253 & 168 & $6.00 \pm 0.09$ & 168 & $5.75 \pm 0.09$ & 0.054 \\
\hline Protein, \% & 276 & $4.86 \pm 0.02$ & 60 & $5.02 \pm 0.05$ & 0.006 & 168 & $5.04 \pm 0.04$ & 168 & $4.84 \pm 0.04$ & 0.001 \\
\hline $\mathrm{FCM},{ }^{4} \mathrm{~kg}$ & 276 & $1.22 \pm 0.02$ & 60 & $0.86 \pm 0.05$ & 0.001 & 168 & $0.96 \pm 0.04$ & 168 & $1.12 \pm 0.04$ & 0.007 \\
\hline BW change, ${ }^{6} \mathrm{~kg}$ & 46 & $-12.95 \pm 0.81$ & 10 & $-12.43 \pm 1.74$ & 0.788 & 28 & $-15.39 \pm 1.35$ & 28 & $-9.99 \pm 1.35$ & 0.007 \\
\hline BCS change $^{7}$ & 46 & $-0.49 \pm 0.06$ & 10 & $-0.23 \pm 0.13$ & 0.070 & 28 & $-0.61 \pm 0.10$ & 28 & $-0.11 \pm 0.10$ & 0.001 \\
\hline
\end{tabular}

${ }^{1}$ Late-lactation ewes were $136 \pm 9 \mathrm{DIM}$, and early-lactation ewes were $21 \pm 10$ DIM at the start of the trial.

${ }^{2}$ The supplement treatment group received $0.82 \mathrm{~kg}$ of DM/d per ewe.

${ }^{3} \mathrm{n}=$ number of observations.

${ }^{4} 6.5 \% \mathrm{FCM}$.

${ }^{5} 6.5 \%$ fat- and $5.8 \%$ protein-corrected milk.

${ }^{6}$ Calculated as final BW minus initial BW.

${ }^{7}$ Calculated as final BCS minus initial BCS. 


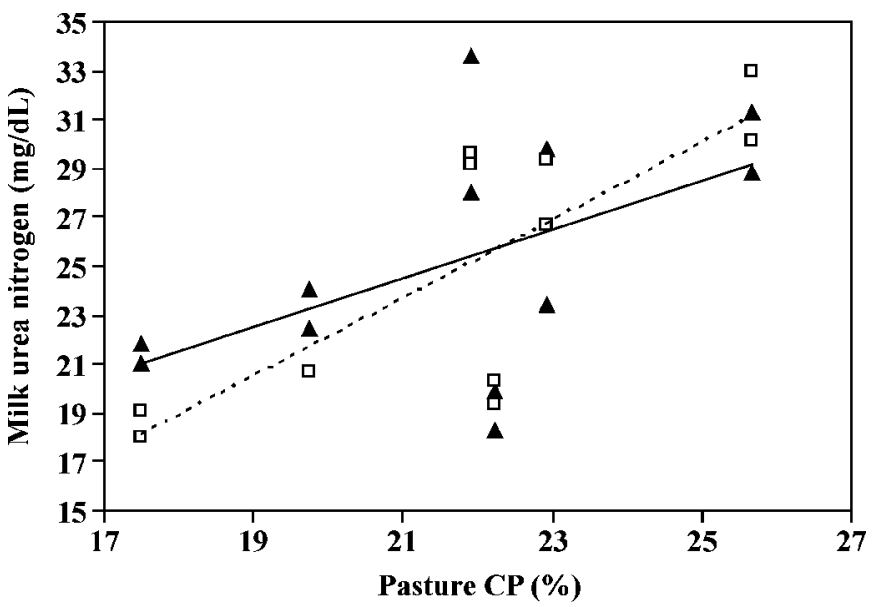

Figure 4. Relationship between MUN and test-day pasture $\mathrm{CP}$ (\% of DM) within supplemented $(\mathbf{\Delta} ; \mathrm{r}=0.52)$ and unsupplemented $(\square ; \mathrm{r}=0.78)$ treatments. Plots of the regression of MUN on pasture CP (\% of DM) within supplementation treatments [supplemented: solid line, $\mathrm{MUN}(\mathrm{mg} / \mathrm{dL})=1.00 \mathrm{CP}+3.62, \mathrm{R}^{2}=0.27$; unsupplemented: broken line, $\left.\mathrm{MUN}(\mathrm{mg} / \mathrm{dL})=1.60 \mathrm{CP}+9.91, \mathrm{R}^{2}=0.61\right]$.

ture NDF was below the average (28.0 and $23.8 \%$, respectively, vs. $41.9 \%$ average). A lower milk fat percentage also has been documented in supplemented, compared with unsupplemented, dairy cows grazing pasture (Reis and Combs, 2000).

Late-lactation ewes had a greater $(P=0.006)$ milk protein percentage than early-lactation ewes (5.02 vs. $4.86 \%$, respectively; Table 3). This supports previous reports in which milk protein percentage increased throughout lactation as milk production decreased (Cappio-Borlino et al., 1997). Unsupplemented ewes had a higher $(P=0.001)$ milk protein percentage than supplemented ewes (5.04 vs. $4.84 \%$, respectively; Table 3).

MUN. Milk urea N levels are closely related to blood urea $\mathrm{N}$ levels in sheep and can be used as an indicator of protein utilization (Cannas et al., 1998). In trial 1, there was no effect of stage of lactation or supplementation on MUN levels (Table 3). Trial MUN values ranged from 18 to $34 \mathrm{mg} / \mathrm{dL}$ and were generally higher than the recommended levels for sheep (14 to $22 \mathrm{mg} / \mathrm{dL}$; Cannas, 2002), indicating excess $\mathrm{N}$ or insufficient energy intake. This may be partially explained by the high CP content of the pastures, which ranged from 16 to $30 \% \mathrm{CP}$.

The utilization of dietary protein depends on both protein and energy intake (Oltner and Wiktorsson, 1983). Across all treatments, the correlation between pasture CP and MUN was 0.65 . Within the unsupplemented treatment, the correlation (0.78) was numerically higher, but not significantly different, from the correlation within the supplemented treatment $(0.52$; Figure 4). Unsupplemented ewes were more dependent on pasture for both protein and energy than were supplemented ewes, so a higher correlation between pasture CP and MUN would be expected in unsupplemented ewes. Supplemented ewes had energy available from the concentrate to use dietary protein, but the supplement also was $16.5 \% \mathrm{CP}$, confounding the effects of energy from the supplement on protein utilization from the pasture.

High levels of circulating urea have been associated with low reproductive efficiency in Italian dairy ewes (Bishonga et al., 1996), and $\mathrm{NH}_{3}$ detoxification may increase the energy requirements of ewes (Cannas, 2002). The high MUN values in all treatments suggested that the pastures provided excess degradable $\mathrm{N}$; however, protein in the supplement made the utilization of pasture protein difficult to determine. On the basis of the high MUN levels in this trial, trial 2 was conducted using only whole corn supplementation.

$B W$ and BCS Change. There were no significant interactions between stage of lactation and supplementation treatment for BW change or BCS change. Body weight loss during the trial was greater $(P=0.007)$ in unsupplemented ewes compared with supplemented ewes ( -15.39 vs. $-9.99 \mathrm{~kg}$, respectively; Table 3). The Cornell Net Carbohydrate and Protein System (Cannas et al., 2004) predicted that the unsupplemented ewes would lose $7.38 \mathrm{~kg}$ more BW than the supplemented ewes during the trial, which is similar to the observed $5.40 \mathrm{~kg}$ of BW loss in the unsupplemented ewes compared with the supplemented ewes. Changes in BCS reflected changes in BW; unsupplemented ewes had a more $(P=0.001)$ negative change in BCS than did supplemented ewes ( -0.11 vs. -0.61 , respectively) during the trial.

There was no difference in BW change for ewes in early and late lactation (Table 3). However, ewes in early lactation tended $(P=0.07)$ to lose more body condition compared with ewes in late lactation ( -0.49 vs. -0.23 , respectively). Loss of body condition in earlylactation ewes can be attributed to energy demand for greater $(P=0.001)$ daily milk production (Table 3$)$.

\section{Trial 2}

Milk Production and Composition. Average daily milk production increased $(P<0.001)$ linearly in response to increased amounts of corn grain supplementation (Table 4). Ewes supplemented with $0.41,0.82$, and $1.24 \mathrm{~kg}$ of DM/d per ewe of corn produced $1.5 \%$ (not significant), $8.5 \%(P<0.05)$, and $10.8 \%(P<0.05)$ more milk, respectively, than did unsupplemented ewes. Reis and Combs (2000) observed a similar linear increase in milk yield in dairy cattle in response to an increase in the amount of corn-based supplement. The milk yield 
Table 4. Performance of grazing dairy ewes offered $0,0.41,0.82$, and $1.24 \mathrm{~kg}$ of DM/d per ewe of whole corn in trial 2

\begin{tabular}{|c|c|c|c|c|c|c|c|c|}
\hline \multirow[b]{3}{*}{ Item } & \multirow{2}{*}{\multicolumn{4}{|c|}{ Level of supplementation }} & \multirow[b]{3}{*}{ SEM } & \multirow{3}{*}{$\begin{array}{c}\text { Treatment, } \\
P \text {-value }\end{array}$} & \multicolumn{2}{|c|}{ Contrast } \\
\hline & & & & & & & Linear & Quadratic, \\
\hline & 0 & 0.41 & 0.82 & 1.24 & & & $P$-value & $P$-value \\
\hline Milk, kg/d & $1.30^{\mathrm{a}}$ & $1.32^{\mathrm{a}}$ & $1.41^{\mathrm{b}}$ & $1.44^{\mathrm{b}}$ & 0.03 & 0.001 & 0.001 & 0.899 \\
\hline Fat, \% & $6.26^{\mathrm{b}}$ & $6.40^{\mathrm{b}}$ & $6.09^{\mathrm{b}}$ & $5.89^{\mathrm{a}}$ & 0.11 & 0.001 & 0.001 & 0.031 \\
\hline Fat, g/d & 80.7 & 80.6 & 85.9 & 83.2 & 1.80 & 0.124 & 0.117 & 0.471 \\
\hline Protein, \% & 5.29 & 5.41 & 5.37 & 5.39 & 0.04 & 0.070 & 0.093 & 0.132 \\
\hline Protein, g/d & $68.6^{\mathrm{a}}$ & $69.5^{\mathrm{a}}$ & $76.1^{\mathrm{b}}$ & $76.4^{\mathrm{b}}$ & 1.60 & 0.001 & 0.001 & 0.862 \\
\hline $\mathrm{FCM},{ }^{1} \mathrm{~kg} / \mathrm{d}$ & $1.27^{\mathrm{a}}$ & $1.26^{\mathrm{a}}$ & $1.36^{\mathrm{b}}$ & $1.34^{\mathrm{b}}$ & 0.03 & 0.030 & 0.012 & 0.660 \\
\hline $\mathrm{FPCM},{ }^{2} \mathrm{~kg} / \mathrm{d}$ & $1.26^{\mathrm{ab}}$ & $1.25^{\mathrm{a}}$ & $1.35^{\mathrm{c}}$ & $1.33^{\mathrm{bc}}$ & 0.03 & 0.013 & 0.006 & 0.667 \\
\hline MUN, mg/dL & $18.93^{\mathrm{a}}$ & $17.11^{\mathrm{b}}$ & $13.58^{\mathrm{c}}$ & $13.62^{\mathrm{c}}$ & 0.33 & 0.001 & 0.001 & 0.005 \\
\hline BW change, ${ }^{3} \mathrm{~kg}$ & $-2.38^{\mathrm{a}}$ & $-1.46^{\mathrm{ab}}$ & $-0.04^{\mathrm{ab}}$ & $0.51^{\mathrm{b}}$ & 0.71 & 0.021 & 0.022 & 0.792 \\
\hline BCS change ${ }^{4}$ & $-0.33^{\mathrm{a}}$ & $-0.19^{\mathrm{ab}}$ & $-0.08^{b}$ & $-0.06^{b}$ & 0.07 & 0.046 & 0.007 & 0.403 \\
\hline
\end{tabular}

response to increased amounts of corn supplementation in the present trial may be the result of increased energy available for microbial growth, stimulating the production of glucogenic precursors, such as propionate for lactose production in the mammary gland. In addition, increased microbial growth from supplemental starch may have reduced the ruminal $\mathrm{NH}_{3}$ load, thus decreasing the energy cost for ureagenesis.

Milk fat percentage decreased quadratically $(P<0.05$; Table 4) as the level of supplementation increased. Ewes receiving $1.24 \mathrm{~kg} / \mathrm{d}$ of supplement had the lowest milk fat percentage. In Italian dairy ewes producing more than $1.2 \mathrm{~kg}$ of milk/d, milk fat percentage was closely and inversely associated with dietary fiber intake and energy balance (Pulina et al., 2007). Thus, ewes in the $1.24 \mathrm{~kg} / \mathrm{d}$ treatment may have been in a more positive energy balance and may have contributed less of their body reserves to milk fat. In addition, these ewes may have consumed less of the higher fiber forage because of the substitution effect of grain (Avondo, 2005), reducing dietary NDF intake and milk fat percentage. In grazing dairy cattle, Reis and Combs (2000) found a linear decrease in milk fat concentration with increasing corn supplementation, supporting the negative effect of dietary carbohydrates on milk fat percentage. Milk fat yield was not affected by supplementation treatments because of the opposite effects of increased corn supplementation on milk yield and milk fat percentage.

Milk protein percentage tended to increase $(P=0.07)$ linearly with increasing corn supplementation (Table 4). These results are supported by Cannas et al. (2003), who reported a positive association between milk protein and dietary energy concentration in dairy ewes.
Total protein production increased $(P<0.001)$ linearly with increased supplementation level, primarily because of increased milk yield as the supplementation amount increased.

The increased level of corn supplementation resulted in a linear increase in FCM $(P=0.012)$ and $\operatorname{FPCM}(P=$ 0.006). Reis and Combs (2000) noted a similar effect of corn supplementation on yields of $4 \% \mathrm{FCM}$ and SCM in dairy cattle. These results are particularly relevant for dairy sheep because the primary use of sheep milk is in cheese production, and protein and fat content are important in determining cheese yield.

MUN. Milk urea $\mathrm{N}$ levels decreased quadratically $(P=0.005)$ as the level of corn supplementation increased (Table 4). The MUN levels of the 3 treatment groups receiving corn supplementation were lower $(P$ $<0.05)$ than the MUN level of the unsupplemented ewes. Cannas et al. (2003) found that dairy ewes on high NFC diets (35\% of DM) had lower MUN concentrations than ewes on low NFC diets (23\% of DM).

These results support the idea that increased $\mathrm{N}$ utilization through microbial growth can be attained by increasing carbohydrates in diets high in RDP. In a summary of nutrition studies on dairy sheep, Giovanetti (2006) found that the concentration of milk urea could be predicted by the ratio of $\mathrm{CP}$ to $\mathrm{NE}_{\mathrm{L}}$. This predictive equation is based on pen-feeding studies conducted with stored feeds, but our results suggest the potential for creation of a predictive equation for MUN based on grazed forages.

BW and BCS Change. Body weight change during the trial was linearly $(P=0.022)$ related to the level of supplementation (Table 4). Only the $1.24 \mathrm{~kg}$ of $\mathrm{DM} / \mathrm{d}$ treatment resulted in an increase in $\mathrm{BW}$. Changes in 
BCS reflected changes in BW and were linearly $(P=$ 0.007 ) related to the level of supplementation (Table 4).

\section{Trial Comparison}

Milk Yield. Even though the 2 trials were conducted in different years, the similarity in daily milk yields of unsupplemented ewes in trials 1 and $2(1.36 \mathrm{vs} .1 .30 \mathrm{~kg} /$ $\mathrm{d}$, respectively) suggests that the net effects of pasture, climatic, and other environmental factors influencing milk yield were similar between the 2 years. This allowed some observations and comparisons to be made between trials.

When comparing milk yield response to supplementation of $0.82 \mathrm{~kg}$ of DM/d per ewe, supplementation with CSBM in trial 1 resulted in a milk yield increase of $0.23 \mathrm{~kg} / \mathrm{d}$, whereas supplementation with corn alone in trial 2 resulted in an increase of $0.11 \mathrm{~kg} / \mathrm{d}$. The larger response to the CSBM may be due to a positive effect of RUP on milk yield. Soybean meal contains $23 \%$ RUP (as a percentage of DM), whereas whole corn contains $4 \%$ RUP (as a percentage of DM; NRC, 2001). Both trial groups grazed pastures averaging more than $20 \% \mathrm{CP}$, and pasture protein degradability can be high $(>70 \%$; Holden et al., 1994). Therefore, the increased effect on milk yield from CSBM supplementation suggests a benefit of RUP in dairy sheep diets. In confinement, supplementation of rumen-protected Met and Lys increased milk yield in dairy ewes (Sevi et al., 1998). In dairy cattle on pasture, the results of supplementing RUP sources have been mixed (Bargo et al., 2003).

Another reason for the positive milk yield response to CSBM may have been due to additional energy if the supplemental protein was used for gluconeogenesis. However, in trial 2, supplementation with the highest level of corn (1.24 kg of corn DM/d per ewe) and a high amount of energy increased milk yield by only $0.14 \mathrm{~kg} /$ $\mathrm{d}$ above that of the unsupplemented treatment. The larger milk yield response to CSBM supplementation in trial 1 further supports the role of RUP in increasing milk yield in dairy ewes.

MUN. Milk urea N values were higher in trial 1 than in trial 2 (Tables 3 and 4). Higher average pasture $\mathrm{CP}$ percentages in trial 1 compared with trial $2(+3.6 \%$; Table 2) and higher protein in the CSBM supplement in trial 1 compared with the corn in trial 2 accounted for some of this difference. However, even at similar levels of pasture CP percentages, the unsupplemented treatments in trial 1 had higher MUN values than the unsupplemented treatment in trial 2. Differences in MUN values may be due to differences in analytical procedures between trials. Trial $1 \mathrm{MUN}$ values were determined with a Foss FT6000, whereas trial 2 MUN values were determined by an enzymatic procedure, and values were determined in different laboratories in each trial. Estimates determined by these 2 methods and in these 2 laboratories may not be comparable. Even when using the same analytical method (Foss FT6000), Peterson et al. (2004) found that MUN recovery was inconsistent across laboratories and that recovery was more than $100 \%$ in some laboratories. However, the MUN results from trial 2 still suggest that increased supplemental energy from corn alone can improve pasture protein utilization.

\section{Cost of Supplement}

Sheep milk was valued at $\$ 1.22 / \mathrm{kg}$ in Wisconsin in 2006 (Wisconsin Agricultural Statistics Service, 2006). In trial 1, supplemented ewes produced $0.23 \mathrm{~kg} / \mathrm{d}$ more milk than unsupplemented ewes, increasing income by $\$ 23.01$ during the trial period. If $0.82 \mathrm{~kg}$ of DM of CSBM supplement is provided each day for $82 \mathrm{~d}$ at a price of $\$ 147 /$ ton, the net return over supplement cost is $\$ 9.25 /$ ewe, and supplementation is profitable as long as the supplement costs less than $\$ 0.27 / \mathrm{kg}$. Based on a corn price of $\$ 2.96 / \mathrm{bu}$ or $\$ 0.117 / \mathrm{kg}$ (Iowa Department of Agriculture and Land Stewardship, 2007), the economic return of supplementing $0.41,0.82$, and $1.24 \mathrm{~kg}$ of corn $\mathrm{DM} / \mathrm{d}$ per ewe above no supplement in trial 2 would be $-\$ 2.65, \$ 2.22$, and $\$ 0.52 /$ ewe, respectively, during the 88-d trial period. Break-even prices for corn grain with supplementation at $0.41,0.82$, and $1.24 \mathrm{~kg}$ of corn DM/d per ewe are $\$ 0.052, \$ 0.144$, and $\$ 0.121 / \mathrm{kg}$, respectively.

\section{CONCLUSIONS}

In support of previous studies, dairy ewes in early lactation produced more daily milk than ewes in late lactation. The average milk protein percentage was higher in early-lactation than in late-lactation ewes, but there was no difference in average milk fat percentage due to stage of lactation. Supplementation of grazing dairy ewes with either a mixture of CSBM or corn alone resulted in greater milk production compared with unsupplemented ewes. Increased levels of corn supplementation resulted in a positive, linear increase in milk yield and an improvement in pasture protein utilization, as indicated by a decrease in MUN levels. Supplementation with a mixture of corn and soybean meal did not improve pasture protein utilization but did increase milk yield, suggesting a positive effect of RUP on the milk yield of dairy ewes. On the basis of the current price of sheep milk, supplementation of $0.82 \mathrm{~kg}$ of $\mathrm{DM} / \mathrm{d}$ per ewe of CSBM is profitable if the supplement costs less than $\$ 0.27 / \mathrm{kg}$, and supplementation of $0.82 \mathrm{~kg}$ of $\mathrm{DM} / \mathrm{d}$ per ewe of whole corn is profitable if the corn price is below $\$ 0.14 / \mathrm{kg}$. 


\section{REFERENCES}

Avondo, M. 2005. Prediction of feed intake in the Italian dairy sheep. Ital. J. Anim. Sci. 4:35-44.

Bargo, F., L. D. Muller, E. S. Kolver, and J. E. Delahoy. 2003. Invited review: Production and digestion of supplemented dairy cows on pasture. J. Dairy Sci. 86:1-42.

Bishonga, C., J. J. Robinson, T. G. Mcevoy, P. Findlay, R. P. Aitken, and I. Robertson. 1996. Excess dietary urea intake in ewes and its effect on ovulation rate and embryo development. Jpn. J. Vet. Res. 44:139-151.

Boundy, T. 1982. Body condition scoring of sheep. Progr. Sheep Breeder Spring:22-24.

Bransby, D. I., A. G. Matches, and G. F. Krause. 1977. Disk meter for rapid estimation of herbage yield in grazing trials. Agron. J. 69:393-396.

Cannas, A. 2002. Feeding of lactating ewes. Pages 123-166 in Dairy Sheep Feeding and Nutrition. G. Pulina, ed. Avenue Media, Bologna, Italy.

Cannas, A., A. Cabiddu, G. Bomboi, S. Ligios, and G. Molle. 2003. Effects of dietary non-fiber carbohydrates concentration on intake, in vivo digestibility and milk yield in Sarda ewes. Proc. 54th Int. Mtg. EAAP, Rome, Italy. Wageningen Acad. Publ., Wageningen, the Netherlands.

Cannas, A., A. Pes, R. Mancuso, B. Vodret, and A. Nudda. 1998 Effect of dietary energy and protein concentration on the concentration of milk urea nitrogen in dairy ewes. J. Dairy Sci. 81:499-508.

Cannas, A., L. O. Tedeschi, D. G. Fox, A. N. Pell, and P. J. Van Soest. 2004. A mechanistic model for predicting the nutrient requirements and feed biological values for sheep. J. Anim. Sci. 82:149-169.

Cappio-Borlino, A., B. Portolano, M. Todaro, N. P. P. Macciotta, P. Giaccone, and G. Pulina. 1997. Lactation curves of Valle del Belice dairy ewes for yields of milk, fat, and protein estimated with test day models. J. Dairy Sci. 80:3023-3029.

Carta, A., S. R. Sanna, and S. Casu. 1995. Estimating lactation curves and seasonal effects for milk, fat and protein in Sarda dairy sheep with a test day model. Livest. Prod. Sci. 44:37-44.

Chaney, A. L., and E. P. Marbach. 1962. Modified reagents for determination of urea and ammonia. Clin. Chem. 8:130-132.

D’Urso, G., M. Avondo, and L. Biondi. 1993. Effect of supplementary feeding on grazing behavior of Comisana ewes in a Mediterranean semi-extensive production system. Anim. Feed Sci. Technol. 42:259-272.

Giovanetti, V. 2006. Urea as an indicator of nitrogen metabolism and excretion in dairy sheep. PhD Thesis. Universita Degli Studi di Sassari, Sassari, Italy.

Goering, H. K., and P. J. Van Soest. 1970. Forage Fiber Analyses (Apparatus, Reagents, Procedures, and Some Applications). Agric. Handbook No. 379. ARS-USDA, Washington, DC.
Hintz, R. W., D. R. Mertens, and K. A. Albrecht. 1996. Effects of sodium sulfite on recovery and composition of detergent fiber and lignin. J. AOAC Int. 79:16-22.

Holden, L. A., L. D. Muller, G. A. Varga, and P. J. Hillard. 1994. Ruminal digestion and duodenal nutrient flows in dairy cows consuming grass as pasture, hay, or silage. J. Dairy Sci. 77:3034-3042.

Iowa Department of Agriculture and Land Stewardship. 2007. July Corn Prices. http://www.agriculture.state.ia.us/grainhistory/julycorn2007.html Accessed Aug. 30, 2007.

Mertens, D. R. 2002. Gravimetric determination of amylase-treated neutral detergent fiber in feeds with refluxing in beakers or crucibles: Collaborative study. J. AOAC Int. 85:1217-1240.

NRC. 2001. Nutrient Requirements of Dairy Cattle. 7th rev. ed. Natl. Acad. Press, Washington, DC.

Nudda, A., G. Battacone, R. Bencini, and G. Pulina. 2002. Nutrition and milk quality. Pages 197-228 in Dairy Sheep Feeding and Nutrition. G. Pulina, ed. Avenue Media, Bologna, Italy.

Oltner, R., and H. Wiktorsson. 1983. Urea concentrations in milk and blood as influenced by feeding varying amounts of protein and energy to dairy-cows. Livest. Prod. Sci. 10:457-467.

Peterson, A. B., K. R. French, E. Russek-Cohen, and R. A. Kohn. 2004. Comparison of analytical methods and the influence of milk components on milk urea nitrogen recovery. J. Dairy Sci. 87:1747-1750.

Pulina, G., A. Nudda, G. Battacone, and A. Cannas. 2007. Effects of nutrition on the contents of fat, protein, somatic cells, aromatic compounds, and undesirable substances in sheep milk. Anim. Feed Sci. Technol. 131:255-291.

Pulina, G., A. Serre, A. Cannas, and G. Rossi. 1989. Determinazione e stima del valor energetico di latte di pecore di razza sarda. (Measurement and prediction of energetic value of milk of Sarda ewes.) Atti Soc. Ital. Sci. Vet. 43:1867-1870.

Reis, R. B., and D. K. Combs. 2000. Effects of increasing levels of grain supplementation on rumen environment and lactation performance of dairy cows grazing grass-legume pasture. J. Dairy Sci. 83:2888-2898.

Robertson, J. B., and P. J. Van Soest. 1981. The detergent system of analysis and its application to human food. Pages 123-158 in The Analysis of Dietary Fiber Food. W. P. T. James and O. Theander, ed. Marcel Dekker, New York, NY.

Sevi, A., A. Muscio, L. Cordola, and D. Dantone. 1998. Milk yield of Comisana ewes fed RP methionine and lysine at two levels of dietary protein content. Ital. J. Food Sci. 10:137-146.

Thomas, D. L. 2004. Overview of the dairy sheep sector in Canada and the United States. Pages 166-177 in Proc. 10th Great Lakes Dairy Sheep Symp., Hudson, WI. Univ. Wisc., Madison.

Wisconsin Agricultural Statistics Service. 2006. Wisconsin Dairy Sheep Industry Overview. http://www.nass.usda.gov/ Statistics_by_State/Wisconsin/Publications/Dairy/ dairysheep.pdf Accessed Dec. 20, 2006. 